\title{
Nasopharyngeal Cancer TNM Finding v7
}

National Cancer Institute

\section{Source}

National Cancer Institute. Nasopharyngeal Cancer TNM Finding v7. NCI Thesaurus. Code C88964.

A finding about one or more characteristics of nasopharyngeal cancer, following the rules of the TNM AJCC V7 classification system. 